\title{
Effect of an oral potassium channel activator, BRL 38227, on airway function and responsiveness in asthmatic patients: comparison with oral salbutamol
}

\author{
J C Kidney, R W Fuller, Y M Worsdell, E A Lavender, K F Chung, P J Barnes
}

\begin{abstract}
Background Potassium $\left(\mathrm{K}^{+}\right)$channel activators, such as cromakalim, open ATP sensitive $\mathrm{K}^{+}$channels and relax airway smooth muscle in vitro and inhibit induced bronchoconstriction in vivo in animals. The prolonged half life of cromakalim gives it potential as an oral bronchodilator. The effect of orally administered BRI 38227 (the active enantiomer of cromakalim), at doses of $0.125,0.25$, and $0.5 \mathrm{mg}$, on airway function and airway responsiveness to histamine and methacholine has been investigated in asthmatic patients.
\end{abstract}

Methods Seventeen patients with asthma were studied in three separate randomised double blind, placebo controlled studies. In the first study eight patients with moderately severe asthma were given $0.125,0.25$, and $0.5 \mathrm{mg}$ of $\mathrm{BRL}$ 38227 or placebo, and responses to histamine were assessed before and five hours after treatment. In the second study responses to methacholine were measured before and five hours after 0.125 and $0.5 \mathrm{mg}$ of BRL 38227 or placebo were given to nine patients with mild asthma. In the third study the effect of $0.5 \mathrm{mg}$ of BRL 38227 or placebo was assessed in eight patients with mild asthma. Responses to histamine were measured before treatment and two and five hours after treatment. To provide a positive control study eight subjects who had taken part in studies 1 and 3 were also given oral salbutamol $(8 \mathrm{mg})$ in a placebo controlled, double blind study. Responses to histamine were assessed before and two hours after treatment.

Results BRL 38227 did not cause significant bronchodilatation or changes in airway responsiveness in any of the studies. Headache was reported in 19 of 25 of patients receiving (in some cases twice) $0.5 \mathrm{mg}$ of BRL 38227 . By contrast, oral salbutamol gave significant protection against histamine challenge (geometric mean $2 \cdot 23$ doubling dilutions).

Conclusions After a single oral dose of BRL 38227 no beneficial effect on airway function was detected, despite a high incidence of side effects, which indicates that the orally administered $\mathrm{K}^{+}$channel activator BRL 38227 may not be useful in the management of asthma.

(Thorax 1993;48:130-133)
Potassium $\left(\mathrm{K}^{+}\right)$channels may have an important role in the regulation of airway smooth muscle tone. ${ }^{1}$ Several types of $\mathrm{K}^{+}$channel have been identified. ${ }^{2-4}$ ATP-sensitive $\mathrm{K}^{+}$ channels link the bioenergetic level of the cell to membrane potential; activation of these channels by drugs such as cromakalim relaxes airway smooth muscle in vitro 5 and inhibits induced bronchoconstriction in vivo in animals. ${ }^{6}$

Cromakalim is a racemic compound of the relatively inactive isomer (BRL 38226) and an active $(3 S, 4 R)$ isomer (BRL 38227) that has twice the potency of cromakalim. BRL 38227 relaxes smooth muscle in animal and human airways in vitro. ${ }^{78}$ The potential clinical advantage of cromakalim as a bronchodilator rests in its long half life of about 24 hours, ${ }^{9}$ and orally administered cromakalim has been reported to attenuate nocturnal bronchoconstriction in asthmatic subjects. ${ }^{10}$

We have evaluated the efficacy of orally administered BRL 38227 as a bronchodilator and its effect on histamine induced bronchoconstriction in patients with moderately severe asthma and on histamine and methacholine induced bronchoconstriction in subjects with mild asthma in randomised, double blind, placebo controlled crossover studies. To provide a positive control for an orally administered bronchodilator we also examined the effects of salbutamol on airway responses in the same subjects.

\section{Methods}

SUBJECTS

We studied 17 patients ( 15 male) with asthma, with a mean age of 33 (range 19-56) years. All patients were taking inhaled $\beta_{2}$ adrenergic agonists on demand and nine were taking inhaled corticosteroids (mean dose 0.83 (SE) $0.25 \mathrm{mg} /$ day). One patient was taking a theophylline preparation and one sodium cromoglycate, which were withdrawn 48 hours before each study day. One patient was having hormone replacement therapy (Prempak-C: oestrogen $625 \mu \mathrm{g}$ and norgesterel $150 \mu \mathrm{g}$ ), which continued throughout the study. At entry the mean $\mathrm{PC}_{20}$ (provocative concentration causing a $20 \%$ fall in $\mathrm{FEV}_{1}$ for histamine (eight subjects) was $0.3 \mathrm{mg} / \mathrm{ml}$ (geometric mean (GSE 0.41)) in study 1 and $1.16 \mathrm{mg} / \mathrm{ml}(0.84)$ in study 3 (eight subjects) and for methacholine (nine subjects) $1.15 \mathrm{mg} / \mathrm{ml}(1.33)$ in study 2 . The $\mathrm{FEV}_{1}$ was greater than $60 \%$ of predicted in all patients. 
MATERIALS

Histamine and methacholine (Sigma, Poole) were stored at $-20^{\circ} \mathrm{C}$ and fresh solutions of $64 \mathrm{mg} / \mathrm{ml}$ in saline were made up on each study day. BRL 38227 (SmithKline Beecham, Great Burgh) was given as capsules of $0.125,0.25$, or $0.5 \mathrm{mg}$. Salbutamol (Ventolin, Allen and Hanbury, Greenford) was given in two capsules each containing $4 \mathrm{mg}$. The placebo capsules lactose were identical to the BRL 38227 and salbutamol capsules.

\section{MEASUREMENTS}

$\mathrm{FEV}_{1}$ and vital capacity were measured with a spirometer (Vitalograph, Cambridge) and recorded as the highest of three readings. Bronchial responsiveness was measured by using inhaled spasmogen delivered via a nebuliser, which was attached to a breath activated dosimeter (Mefar, Brescia, Italy). The dosimeter had an output of $11.7 \mu \mathrm{l}$ per inspiration and generated particles with a mass median diameter of $2 \mu \mathrm{m}$. Each breath activated the nebuliser for one second, and the subject then held his or her breath for eight seconds to maximise deposition. Five inspirations of each concentration of bronchoconstrictor were taken. Doubling concentrations of bronchoconstrictor were administered after inhalation of saline vehicle control, starting at $0.06 \mathrm{mg}$, until a fall in $\mathrm{FEV}_{1}$ of $20 \%$ or more $\left(\mathrm{PC}_{20}\right)$ was recorded, the post-saline value of $\mathrm{FEV}_{1}$ being used as baseline. The concentration provoking a fall of $20 \%$ in $\mathrm{FEV}_{1}$ was calculated by using a linear interpolation of the $\log$ of the concentration of the dose of bronchoconstrictor against the fall in $\mathrm{FEV}_{1}$.

\section{CARDIOVASCULAR MONITORING}

Blood pressure was measured with a Dinamap automated sphygnomanometer (Criticon, Tampa, Florida). Patients were supine for 10 minutes before their blood pressure was measured. A repeat measurement was then made after they had stood for two minutes. Heart rate was also recorded by counting the radial pulse. Electrocardiographic (ECG) recordings were made with an automated 12 lead machine (A700 cardiograph, Hewlett Packard, Washington) before the study, as a baseline on each study day, and five hours after administration of drug or placebo.

\section{SYMPTOMS}

Patients were questioned about symptoms before and 4, 5, and 6 and 24 hours after administration of the drug. The time of onset, duration, and intensity of symptoms were recorded.

\section{PROTOCOLS}

All studies were approved by the ethics committee of the Royal Brompton National Heart and Lung Hospitals. Informed written consent was obtained from each patient. Patients abstained from use of their inhaled bronchodilator for a minimum of six hours before each visit and fasted for 12 hours before the study. Measurements were made at the same time of day on each study day.

Study 1 We assessed BRL 38227 at doses of $0.125,0.25$, and $0.5 \mathrm{mg}$ given orally in a placebo controlled double blind crossover trial over four study days, each separated by a week, in eight subjects with moderately severe asthma. $F E V_{1}$, the $P_{20}$ response to inhaled histamine, blood pressure erect and supine, and ECG were assessed before administration of BRL 38227 and then five hours after administration to coincide with peak plasma concentrations of the drug.

Study 2 We assessed the effect of 0.125 and $0.5 \mathrm{mg}$ BRL 38227, as in study 1 , and the $\mathrm{PC}_{20}$ response to inhaled methacholine was measured before and five hours after administration of the drug in nine subjects with mild asthma.

Study 3 We assessed the effect of $0.5 \mathrm{mg}$ of BRL 38227 in eight mildly asthmatic subjects in a double blind placebo controlled study. $\mathrm{FEV}_{1}$ and $\mathrm{PC}_{20}$ histamine, as well as blood pressure erect and supine, were measured before and two and five hours after administration of the drug.

Study 4 In eight patients, who had taken part in studies 1 and 3, a placebo controlled, double blind trial of oral salbutamol $(8 \mathrm{mg})$ was performed. $\mathrm{FEV}_{1}, \mathrm{PC}_{20}$ histamine, and pulse rate were measured before and two hours after administration of the drug. The dose was chosen as a comparable maximum tolerated dose of an oral bronchodilator.

In studies 1 and 2 blood was taken at 5 hours and in study 3 at 2 and 5 hours for measurement of BRL 38227 concentrations.

\section{STATISTICAL ANALYSIS}

$\mathrm{FEV}_{1}, \mathrm{PC}_{20}$, and cardiovascular measurements were compared with placebo measurements by means of Student's paired $t$ test.

\section{Results}

EFFECTS ON FEV 1 AND PC 20

Study 1 There was no significant difference between placebo and treatment groups in either $\mathrm{FEV}_{1}$ or $\mathrm{PC}_{20}$ histamine at 5 hours (table 1, figure).

Study 2 There was no difference in $\mathrm{FEV}_{1}$ or $\mathrm{PC}_{20}$ methacholine between any of the treatment groups at 5 hours (table 1, figure).

Study 3 There was an increase in $\mathrm{PC}_{20}$ from mean baseline values of 3.52 (GSE 1.26 ) to $6.61 \mathrm{mg} / \mathrm{ml}(1.29)$ at 2 hours and $4.69 \mathrm{mg} / \mathrm{ml}$ $(1.45)$ at 5 hours after $0.5 \mathrm{mg}$ BRL 38227 , but this was not statistically significant. There was no change in $\mathrm{FEV}_{1}$ (table 2, figure).

Study 4 Two hours after salbutamol tablets $\mathrm{PC}_{20}$ histamine was increased from a geometric mean of $1.73 \mathrm{mg} / \mathrm{ml}(1.41)$ to $7.69 \mathrm{mg} / \mathrm{ml}$ $(1.48)(\mathrm{p}<0.05$; table 3 , figure). There was 

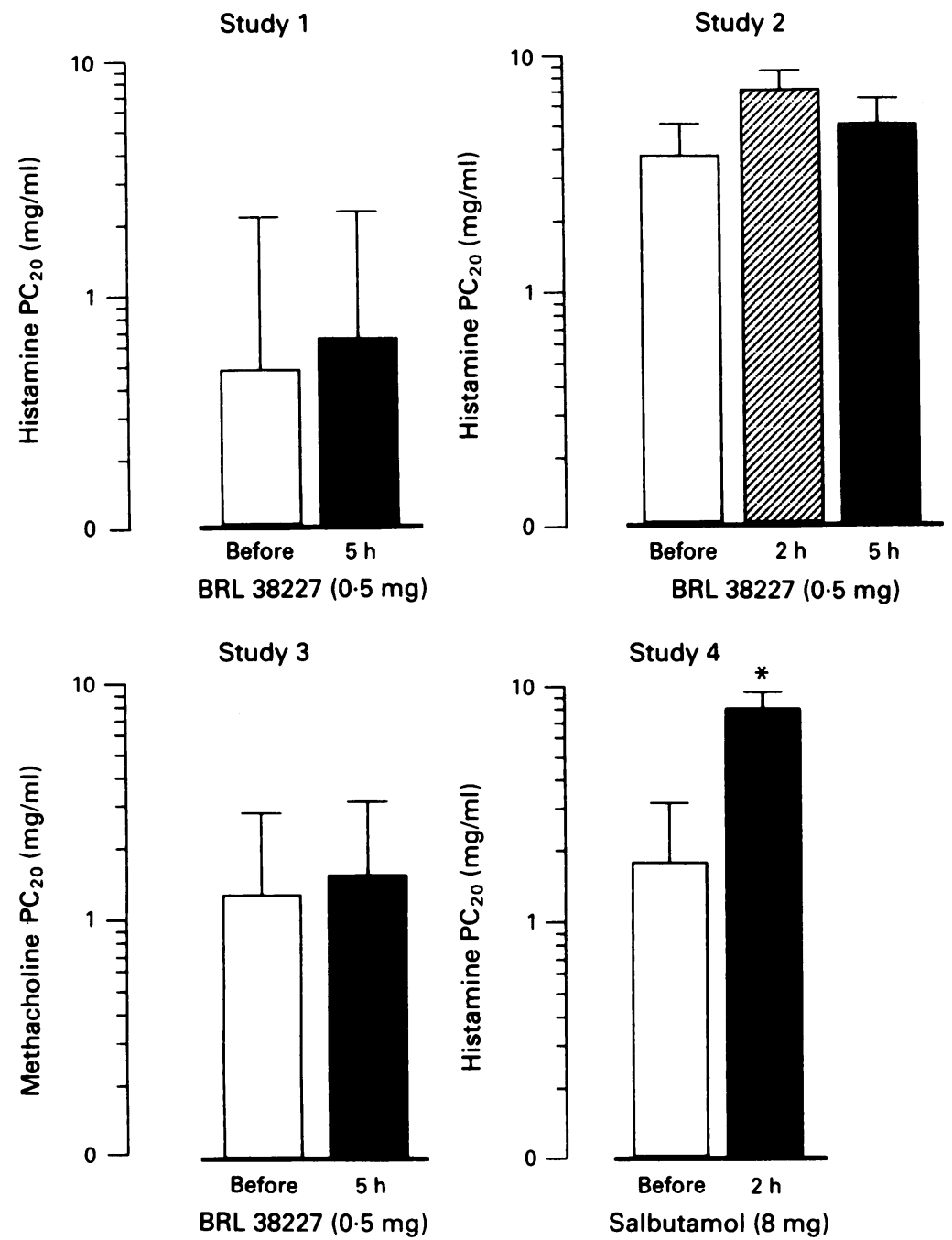

Effect of BRL 38227 ( $0.5 \mathrm{mg}$ orally) and salbutamol ( $8 \mathrm{mg}$ orally) on airway responsiveness in asthmatic patients: geometric mean and GSE values. Bronchial responsiveness to histamine was measured in studies 1,3 , and 4 (eight subjects) and to methacholine in study 2 (nine subjects). The concentration of spasmogen that caused a $20 \%$ fall in $F E V_{1}\left(P C_{20}\right)$ is shown. ${ }^{*} p<0.05$.

also a small mean increase in $\mathrm{FEV}_{1}$ of $0 \cdot 18$ (SE $0.08, \mathrm{p}=0.17$ ) 1. There were no significant changes in $\mathrm{PC}_{20}$ or $\mathrm{FEV}_{1}$ after placebo.

PLASMA CONCENTRATIONS

After single oral doses of $0.5 \mathrm{mg}$ of BRL 38227 the mean blood concentration at 5

Table 1 Effect of oral BRL 38227 on lung function (FEV , mean (SE)) and airway responsiveness $\left(P C_{20}{ }^{\star}\right.$ geometric mean (GSE)) to histamine and methacholine in asthmatic patients

\begin{tabular}{|c|c|c|c|c|}
\hline & \multicolumn{2}{|c|}{ Study $1(n=8)$} & \multicolumn{2}{|c|}{ Study $2(n=9)$} \\
\hline & $F E V_{1}(l)$ & $P C_{20}$ hist $(\mathrm{mg} / \mathrm{ml})$ & $F E V_{1}(l)$ & $P C_{20} m c h(m g / m l)$ \\
\hline \multicolumn{5}{|l|}{ Placebo } \\
\hline $0 \mathrm{~h}$ & $2.99(0.34)$ & $0.35(1.74)$ & $3.13(0.32)$ & $1.5(1.58)$ \\
\hline $5 \mathrm{~h}$ & $2.63(0.34)$ & $0.33(1.74)$ & $3 \cdot 11(0.36)$ & $1 \cdot 71(1 \cdot 86)$ \\
\hline \multicolumn{5}{|l|}{ BRL 38227} \\
\hline \multicolumn{5}{|l|}{$0.125 \mathrm{mg}$} \\
\hline $\mathbf{O h}$ & $2.99(0.33)$ & $0.37(1.45)$ & $3.26(0.33)$ & $1.83(1.58)$ \\
\hline $\begin{array}{c}5 \mathrm{~h} \\
0.25 \mathrm{mg}\end{array}$ & $2 \cdot 78(0.35)$ & $0.40(1.62)$ & $3.02(0.36)$ & $1.69(2.09)$ \\
\hline $0 \mathrm{~h}$ & $2.97(0.32)$ & $0.46(1.55)$ & - & - \\
\hline $\begin{array}{c}5 \mathrm{~h} \\
0.5 \mathrm{mg}\end{array}$ & $2.73(0.31)$ & $0.48(1.62)$ & - & - \\
\hline $\mathrm{Oh}$ & $2.96(0.33)$ & $0.45(1.55)$ & $3.16(0.32)$ & $1 \cdot 27(1.62)$ \\
\hline $5 \mathrm{~h}$ & $2.77(0.33)$ & $0.60(1.51)$ & $3.07(0.37)$ & $1.56(1.66)$ \\
\hline
\end{tabular}

*Calculated by interpolation of the log of the concentration.

FEV ${ }_{1}$ - forced expiratory volume in one second; $\mathrm{PC}_{20}$ hist, $\mathrm{PC}_{20} \mathrm{mch}$ - provocative concentration of histamine or methacholine causing a $20 \%$ or greater fall in $\mathrm{FEV}_{1}$.
Table 2 Effect of oral BRL 38227 on lung function $\left(F E V_{1}\right.$, mean (SE)) and airway responsiveness to histamine $\left(P C_{20}\right.$ hist, ${ }^{\star}$ geometric mean $\left.(G S E)\right)$ in eight asthmatic patients (study 3 )

\begin{tabular}{lll}
\hline & $F E V_{1}(l)$ & $P C_{20}$ hist $(\mathrm{mg} / \mathrm{ml})$ \\
\hline Placebo & & \\
$0 \mathrm{~h}$ & $4.26(0.31)$ & $3.22(1.25)$ \\
$2 \mathrm{~h}$ & $4.20(0.28)$ & $4.39(1.48)$ \\
$5 \mathrm{~h}$ & $4.17(0.26)$ & $4.22(1.38)$ \\
& & \\
BRL 38227 $(0.5 \mathrm{mg})$ & & \\
$0 \mathrm{~h}$ & $4.15(0.23)$ & $3.52(1.26)$ \\
$2 \mathrm{~h}$ & $4.14(0.25)$ & $6.61(1.29)$ \\
$5 \mathrm{~h}$ & $4.06(0.24)$ & $4.69(1.45)$ \\
\hline
\end{tabular}

*Calculated by interpolation of the log of the concentration.

hours was $5 \cdot 2$ (range $4 \cdot 0-7 \cdot 3$ ) $\mathrm{ng} / \mathrm{ml}$ in study $1,5 \cdot 0$ (range $2 \cdot 8-6 \cdot 8$ ) $\mathrm{ng} / \mathrm{ml}$ in study 2 , and 6.2 (range $4.9-7.5) \mathrm{ng} / \mathrm{ml}$ in study 3 . The two hour sample in study 3 had a mean blood concentration of $7 \cdot 1$ (range $5 \cdot 3-9 \cdot 5) \mathrm{ng} / \mathrm{ml}$.

\section{SIDE EFFECTS}

The most frequent side effect after BRL 38227 was headache. This occurred in one patient in the first study taking $0.125 \mathrm{mg}$ BRL 38227, in four out of eight patients after $0.25 \mathrm{mg}$, and in six out of eight patients after $0.5 \mathrm{mg}$. Three patients developed headache with placebo. In the second study four out of nine patients reported headache with $0.125 \mathrm{mg}$ BRL 38227 and seven out of nine patients had the same problem with $0.5 \mathrm{mg}$ BRL 38227. In the third study headache occurred in six out of eight patients after $0.5 \mathrm{mg}$ BRL 38227. The headache occurring with the highest dose started usually two to four hours after administration of the drug and lasted a mean 5 hours and 40 minutes (range $1 \mathrm{~h} 20 \mathrm{~min}$ to $13 \mathrm{~h} 30 \mathrm{~min}$ ). After oral salbutamol three patients complained of palpitations.

There was no statistically significant change in blood pressure supine and standing after $0.5 \mathrm{mg}$ BRL 38227. In study 1 , however, one patient developed symptomatic postural hypotension when taking $0.5 \mathrm{mg}$ of BRL 38227 (fall of $26 \mathrm{~mm} \mathrm{Hg}$ ) and one patient when taking placebo (fall of $53 \mathrm{~mm} \mathrm{Hg}$ ). In study 2 one patient developed symptomatic postural hypotension $(39 \mathrm{~mm} \mathrm{Hg}$ ) after $0 \cdot 125$ $\mathrm{mg}$ of BRL 38227. One further patient had an episode of transient lightheadedness on standing while taking the same dose, which was reported after the event; but there was no

Table 3 Effect of oral salbutamol on lung function ( $F E V_{1}$, mean (SE)) and airway responsiveness to histamine $\left(P C_{20}\right.$ hist, ${ }^{\star}$ geometric mean (GSE)) in eight asthmatic patients

\begin{tabular}{lll}
\hline & $F E V_{1}(l)$ & $P C_{20}$ hist $(\mathrm{mg} / \mathrm{ml})$ \\
\hline Placebo & & \\
$0 \mathrm{~h}$ & $3.68(0.42)$ & $1.42(1.45)$ \\
$2 \mathrm{~h}$ & $3.70(0.45)$ & $1.86(1.55)$ \\
Salbutamol (8 mg) & & \\
$0 \mathrm{~h}$ & $3.69(0.44)$ & $1.73(1.41)$ \\
$2 \mathrm{~h}$ & $3.87(0.47)$ & $7.69(1.48)$ \\
\hline
\end{tabular}

*Calculated by interpolation of the $\log$ of the concentration. 
demonstrable postural change in blood pressure. In study 3 there were no episodes of symptomatic postural hypotension. Heart rate and ECG did not change during the BRL 38227 treatment. In study 4 the mean (SE) heart rate rose from $73(2.56)$ to $87(3 \cdot 76)$; $\mathrm{p}<0.05)$ after oral salbutamol.

\section{Discussion}

We have shown that single oral doses of BRL 38227 had no significant effect on lung function or airway responsiveness to histamine or methacholine. By contrast, in a subgroup of these patients a high dose of the oral $\beta_{2}$ agonist salbutamol significantly attenuated airway responsiveness to inhaled histamine.

$\mathrm{K}^{+}$channel activation relaxes airway smooth muscle and inhibits agonist induced bronchoconstriction in vitro ${ }^{5}$ and in vivo. ${ }^{6}$ Cromakalim, a racemic mixture of BRL 38227 and the inactive BRL 38226, has been shown to attenuate the early morning fall in $\mathrm{FEV}_{1}$ in patients with asthma. BRL 38227, the active enantiomer of cromakalim, also relaxes airway smooth muscle in vitro ${ }^{78}$ and, like cromakalim, has a long plasma half life and is therefore of potential use as a bronchodilator in asthma. ${ }^{910}$

It has previously been reported that cromakalim ( $2 \mathrm{mg}$ orally) protected against histamine induced bronchoconstriction in normal subjects, in contrast to the findings in this study with its active enantiomer. ${ }^{11}$ Possibly the relatively inert enantiomer BRL 38226 had some beneficial role, but this seems very unlikely. The reason for the failure of BRL 38227 to cause bronchodilatation or to protect against induced bronchoconstriction in asthmatic patients in the present study is not certain, but may be related to the dose that can be tolerated. If higher doses were administered it is likely that a bronchodilator effect would occur as this drug is effective in human airways in vitro and reverses contraction induced by both histamine and a cholinergic agonist. ${ }^{78}$ Higher oral doses may be precluded, however, because at the highest dose given almost all of the subjects complained of headache, which is presumably related to the peripheral vasodilator action of the drugthough changes in blood pressure were minimal. Another possible reason for the lack of effect of BRL 38227 may be that oral bronchodilators do not affect airway responsiveness to the extent that is observed with inhaled drugs. Thus oral salbutamol does not protect against exercise induced asthma, whereas an equivalent bronchodilator dose by inhalation gives good protection, ${ }^{12}$ presumably because of better access to surface cells. In the present study, however, we found that high dose oral salbutamol gave good protection against histamine induced bronchoconstriction in the same subjects. Possibly lower doses of salbutamol would not give the same protection; but the dose of $8 \mathrm{mg}$ was chosen to compare a maximal dose of an oral bronchodilator with the highest dose of BRL 38227 , to provide a positive control.
Lung function and airway responsiveness have been measured five hours after administration of the drug as this time coincides with peak plasma concentrations of BRL $38227 ;^{9}$ in our study, however, the two hour levels were higher. In view of the lack of effect after five hours we also examined responses two hours after dosing but this also failed to show any activity of the drug.

This is the first reported study of an oral $\mathrm{K}^{+}$channel activator in relation to baseline airway function and reactivity in asthmatic subjects. After single doses we were unable to show any beneficial effect, but possibly more prolonged dosing would have some effect once steady state tissue concentrations were achieved. Possibly also with long term dosing cardiovascular side effects become less common. For use in asthma, $\mathrm{K}^{+}$channel activators may need to be given by inhalation to achieve higher concentrations in the airways, although whether a particular $\mathrm{K}^{+}$channel activator will be effective by inhalation will depend on its pharmacokinetic properties. In view of the increasing diversity of known $\mathrm{K}^{+}$ channels it may be possible in the future to develop new $\mathrm{K}^{+}$channel activators that have a greater selectivity for $\mathrm{K}^{+}$channels in airway smooth muscle, thus allowing higher doses to be given. There is preliminary evidence that the development of a more airway selective ATP sensitive $\mathrm{K}^{+}$channel activator is possible. ${ }^{13}$ Further studies on this class of drug in asthma are warranted if greater airway selectivity can be obtained either with the inhaled route or by development of more airway selective drugs.

1 Black JL, Barnes PJ. Potassium channels and airway function: new therapeutic prospects. Thorax 1990;45:213-8.

Pongs $O$. The molecular basis of potassium channel diversity. Pflugers Arch 1989;414:S7 1-5.

3 Frech GC, Van Dongen AM, Schuster G, Brown AM, Joho RH. A novel potassium channel with delayed rectifier properties, isolated from rat brain by expression cloning. Nature 1989;340:642-5.

4 Cook NS. The pharmacology of potassium channels and their therapeutic potential. Trends Pharmacol Sci 1988;9:21-8.

5 Allen SL, Boyle JP, Cortijo J, Foster RW, Morgan GP, Small RC. Electrical and mechanical effects of BRL 34915 in guinea-pig isolated trachealis. $\mathrm{Br} \mathcal{F}$ Pharmacol 1986;89:395-405.

6 Arch JRS, Buckle DR, Bumstead J, Clarke GD, Taylor JF, Taylor SG. Evaluation of the potassium channel activator cromakalim (BRL 34915) as a bronchodilator in the guinea pig: comparison with nifedipine. $\mathrm{Br} \mathcal{F}$ in the guinea pig: compariso

7 Black JL, Armour CL, Johnson PR, Alouan LA, Barnes PJ. The action of a potassium channel activator, BRL 38227 (lemakalim), on human airway smooth muscle. Am Rev Respir Dis 1990;142:1384-9.

8 Taylor SG, Bumstead J, Morris JEJ, Shaw DJ, Taylor JF. Cromakalim inhibits cholinergic mediated responses in human isolated bronchioles but not in guinea-pig airways. Br f Pharmacol 1988;95:795P.

9 Gill TS, Davies BE, Tasker EM, Whitehead EM, Fox J, Shanks RG. Stereospecific pharmacokinetics of cromakalim enantiomers at various oral dose levels, in healthy male subjects. Br $\mathcal{f}$ Clin Pharmacol 1988;26: 658P.

10 Williams AJ, Lee TH, Cochrane GM, Hopkirk A, Vyse T, Chiew $\mathrm{F}$, et al. Attenuation of nocturnal asthma by cromakalim. Lancet 1990;336:334-6.

11 Baird A, Hamilton TC, Richards DH, Tasker, Williams AJ. Inhibition of histamine induced bronchoconstriction in normal healthy volunteers by a potassium channel activator, BRL 34915. Br $\mathcal{F}$ Clin Pharmacol 1988;25: $114 \mathrm{P}$.

12 Anderson SD, Seale JP, Rozea P, Bandler L, Theobald G, Lindsay DA. Inhaled and oral salbutamol in exerciseinduced asthma. Am Rev Respir Dis 1976;114:493-500.

13 Bowring NE, Buckle DR, Taylor JF, Arch JFS. BRI 55834: A novel potassium channel activator that is more selective for the airways in the guinea pig and rat compared to BRL 38227. Br f Pharmacol 1992;104:73P. 